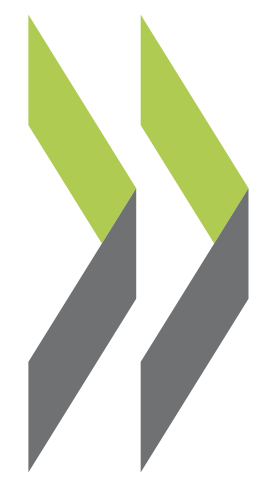

OECD Economics Department Working Papers No. 1192

Improving the Business

Artur Radziwill,

Climate in Russia

Yana Vaziakova

https://dx.doi.org/10.1787/5js4hmd6kq32-en 
Organisation de Coopération et de Développement Économiques

Organisation for Economic Co-operation and Development

25-Mar-2015

ECONOMICS DEPARTMENT

English - Or. English

\title{
IMPROVING THE BUSINESS CLIMATE IN RUSSIA
}

ECONOMICS DEPARTMENT WORKING PAPERS No. 1192

\author{
By Artur Radziwill and Yana Vaziakova
}

OECD Working Papers should not be reported as representing the official views of the OECD or of its member countries. The opinions expressed and arguments employed are those of the author(s).

Authorised for publication by Robert Ford, Deputy Director, Country Studies Branch, Economics Department.

All Economics Department Working Papers are available at www.oecd.org/eco/workingpapers

JT03373080

Complete document available on OLIS in its original format

This document and any map included herein are without prejudice to the status of or sovereignty over any territory, to the delimitation of international frontiers and boundaries and to the name of any territory, city or area. 
OECD Working Papers should not be reported as representing the official views of the OECD or of its member countries. The opinions expressed and arguments employed are those of the author(s).

Working Papers describe preliminary results or research in progress by the author(s) and are published to stimulate discussion on a broad range of issues on which the OECD works.

Comments on Working Papers are welcomed, and may be sent to OECD Economics Department, 2 rue André-Pascal, 75775 Paris Cedex 16, France, or by e-mail to eco.contact@oecd.org.

This document and any map included herein are without prejudice to the status of or sovereignty over any territory, to the delimitation of international frontiers and boundaries and to the name of any territory, city or area.

The statistical data for Israel are supplied by and under the responsibility of the relevant Israeli authorities. The use of such data by the OECD is without prejudice to the status of the Golan Heights, East Jerusalem and Israeli settlements in the West Bank under the terms of international law.

\section{(c) OECD (2015)}

You can copy, download or print OECD content for your own use, and you can include excerpts from OECD publications, databases and multimedia products in your own documents, presentations, blogs, websites and teaching materials, provided that suitable acknowledgment of OECD as source and copyright owner is given. All requests for commercial use and translation rights should be submitted to rights@oecd.org 


\section{ABSTRACT/RÉSUMÉ}

\section{Improving the Business Climate in Russia}

Economic growth is below what would be needed to resume rapid convergence to average OECD living standards. On-going efforts to improve the business climate are laudable, but need to be widened and strengthened. Much progress has been achieved in reducing red tape, but it is only recently that the authorities have visibly become more energetic in fighting corruption. Adverse interactions between politics, business and law enforcement generate obstacles for the rule of law and remain a major risk for potential investors. High entry barriers lead to weak competition. Reducing the role of the state in the economy and WTO membership should be viewed as opportunities to strengthen competition, and hence provide incentives for productivity improvements, which are urgently required to ensure stronger growth in Russia because of a shrinking labour force.

This Working Paper relates to the 2013 OECD Economic Survey of the Russian Federation (www.oecd.org/eco/surveys/economic-survey-russian-federation.htm).

JEL Classification: D73, F13, K2, K4, L4, L5, L32, L33, H5, H11, H82

Keywords: corruption, judicial system, business climate, FDI, state-owned-enterprises, privatisation, corporate governance, competition, rule of law, administrative burden, WTO accession.

$* * * * * *$

\section{Améliorer le climat des affaires en Russie}

La croissance économique est inférieure à ce qui serait nécessaire pour assurer une convergence rapide du niveau de vie vers ceux observés en moyenne dans les pays de l'OCDE. Les efforts en cours pour améliorer le climat des affaires sont louables, mais ils doivent être élargis et renforcés. Beaucoup de progrès ont été accomplis dans la réduction des formalités administratives, mais ce n'est que récemment que les autorités sont visiblement devenues plus énergiques dans la lutte contre la corruption. Des interactions indésirables entre la politique, les affaires et l'application de la loi génèrent des obstacles pour l'État de droit et constituent un risque majeur pour les investisseurs potentiels. Des barrières élevées à l'entrée conduisent à une faible concurrence. Une réduction du rôle de l'État dans l'économie et l'adhésion de la Russie à l'OMC devraient être considérée comme une occasion de renforcer la concurrence et d'inciter à améliorer la productivité. Ces incitations sont urgemment nécessaires en Russie afin d'assurer une croissance plus forte dans un contexte de contraction de la main-d'œuvre.

Ce document de travail se rapporte à l'Étude économique de l'OCDE 2013 sur la Fédération de Russie (www.oecd.org/fr/eco/etudes/etude-economique-russie.htm).

Classification JEL : D73, F13, K2, K4, L4, L5, L32, L33, H5, H11, H82

Mots clés : corruption, système judiciaire, climat des affaires, IDE, entreprises publiques, privatisation, gouvernance d'entreprise, concurrence, État de droit, formalités administratives, adhésion à l'OMC. 


\section{TABLE OF CONTENTS}

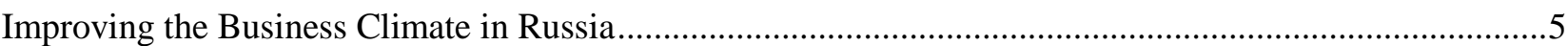

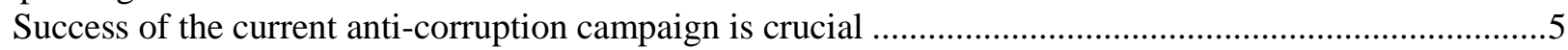

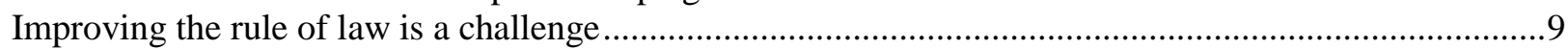

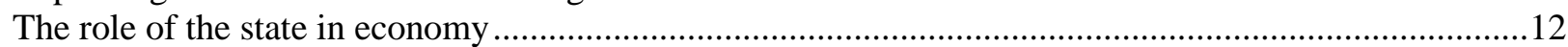

Reforms addressing administrative burden are showing results ........................................................15

Competition policy should become a cornerstone of structural policies ............................................17

WTO membership is an opportunity to promote competition …............................................................

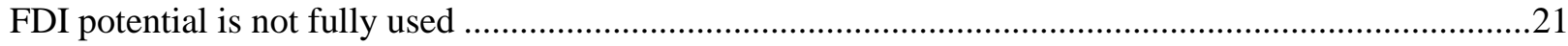

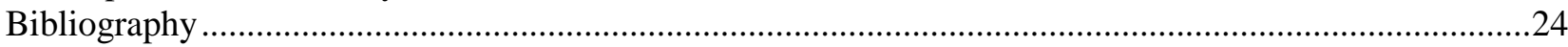

\section{Tables}

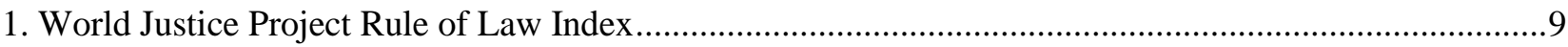

2. Privatisation plan 2012-13 and until 2016 vs. privatisation plan 2014-16 ..........................................14

3. Impact of WTO accession on economy-wide variables in Russia .......................................................19

\section{Figures}

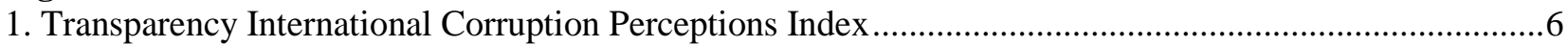

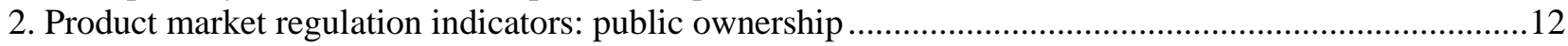

3. State-owned enterprise shares among countries' top ten firms ...............................................................12

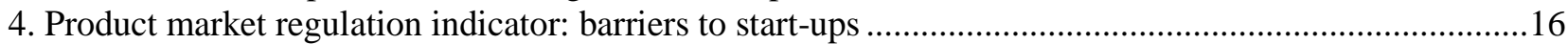

5. Product market regulation indicator: barriers to trade and investment....................................................18

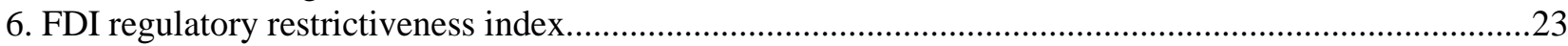

\section{Boxes}

Box 1. Recommendations for establishing a favourable business climate. 
ECO/WKP(2015)10

\title{
IMPROVING THE BUSINESS CLIMATE IN RUSSIA
}

\author{
By \\ Artur Radziwill and Yana Vaziakova ${ }^{1}$
}

A favourable business climate is essential for growth, as demonstrated by experience across OECD countries and beyond. In Russia, re-launching stronger, more balanced and more sustainable growth requires the removal of barriers to private sector entrepreneurship and investment.

\section{Success of the current anti-corruption campaign is crucial}

Russia scores poorly in most corruption assessments. Perceptions of corruption are, according to Transparency International, higher than in all OECD and other BRIICS countries (Figure 1), although the international ranking of Russia has improved since 2010. Particularly worrying is the corruption in law enforcement, which accounted for a quarter of all corruption cases brought to the courts in 2012. The business organisation OPORA states that about $90 \%$ of entrepreneurs have encountered corruption at least once. Bribery in some regions is so widespread that local firms are reported to consider it a convenient alternative to legal and administrative compliance (EBRD, 2012). Moreover, there seems to be only mixed progress in fighting corruption. In a Levada poll $80 \%$ of respondents believed that the level of corruption and fraud nowadays is the same or even higher than a decade ago. According to the World Bank Governance Indicators, corruption was less under control in 2011 than in 2004. On the other hand, a survey by the Public Opinion Foundation (2013) reports that bribes have become less frequent since 2005.

1. Artur Radziwill was Senior Economist at the time of the work and Yana Vaziakova is a consultant in the Economics Department of the OECD. This paper was originally produced and published as part of the chapter "Improving the business climate and transport infrastructure in Russia" of the 2013 OECD Economic Survey of the Russian Federation published in January 2014 on the responsibility of the Secretary General of the OECD. The authors would like to thank the Russian authorities, as well as Andrew Dean, Bob Ford, Andreas Wörgötter, Lilas Demmou, other members of the OECD Secretariat and members of the EDRC for valuable comments and discussions. The paper has benefited from valuable background research by Maria Godunova and Anna Kurguzova. The authors would also like to thank Corinne Chanteloup for statistical assistance and Josiane Gutierrez and Mikel Inarritu for secretarial assistance. 
Figure 1. Transparency International Corruption Perceptions Index Corruption Perception Index 2013 Score, scale from 0 (highly corrupt) to 100 (very clean)

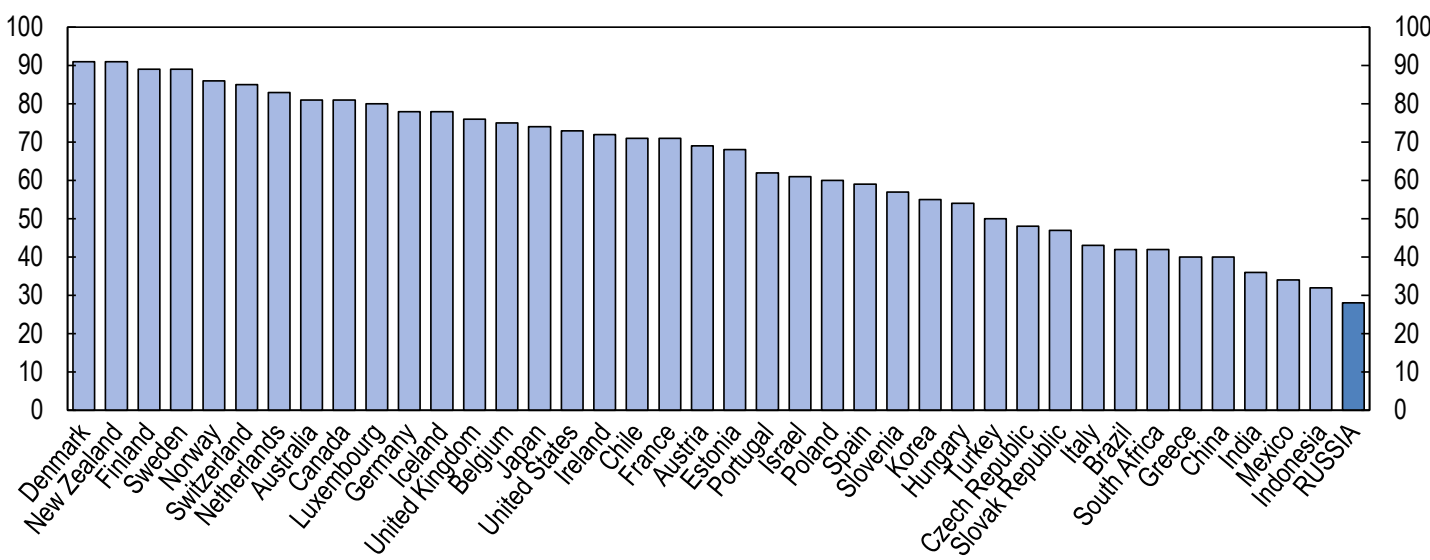

Note: CPI 2013 Score relates to the degree to which corruption is perceived to exist among public officials and politicians by business people and country analysts. Score ranges between 100 (highly clean) and 0 (highly corrupt).

Source: Transparency International, Corruption Perceptions Index 2013.

These assessments are very worrying, because international evidence shows very clearly that corruption is economically and socially costly. It tends to have a strong negative impact on growth (Mauro, 1995; Tanzi, 1995), negatively affecting overall investment (World Bank, 2000) and foreign direct investment (Wei, 2000). It also tends to skew public expenditure away from health and education, presumably because they offer less corruption opportunities (Mauro, 1997). Finally, corruption tends to lead to increased inequality (Gupta et al., 2002).

Russia seems to suffer from corruption-linked ills. The negative impact of corruption on growth is confirmed in cross-country regression analysis including Russian and other transition economies (Mobolaji and Omoteso, 2009). The negative relationship between corruption and growth has also been observed in the Russian regions (Pushkarev, 2007). Foreign investment, other than round-tripping (discussed in later sections of this Chapter), tends to be small. Budgetary spending is biased towards military and other expensive, large-scale projects, while spending on health and education are relatively small. Finally, Russia is among the most unequal countries in the world.

Various surveys confirm the importance of corruption for the Russian economy and society Russian firms see endemic corruption as the major obstacle to market entry and sustainable growth, even though firms assess that the financial cost of corruption has declined during recent years (OPORA, 2012). Corruption is widely seen as the most important country-wide constraint on doing business in Russia (EBRD, 2012). The World Economic Forum Global Competitiveness Report (2013) lists corruption as the most problematic factor for doing business. Among households, corruption appears as the second biggest problem in the country, after housing difficulties but ahead of the bad state of roads according to a survey conducted by the Institute of Contemporary Development (ICD, 2013).

The fight against corruption has gained momentum in the last two years, which could be related to the first signs of improvement in corruption scores. The National Anti-Corruption Plan for 2012-13, signed in March 2012 included a number of important measures. Amendments combating corruption have been introduced into the Criminal Code of Russia and the Code on Administrative Violations. A series of measures aimed at increasing the quality of public governance: 
- All public institutions and state owned enterprises are now obliged to create a commission to consider cases of violation of the provisions of the Code of Ethics and conflict of interest regulations. The monitoring of corruption risk has been strengthened, notably through the introduction of a catalogue of government positions associated with higher corruption risks. These changes have been accompanied by intensive information campaigns directed at civil servants. While there is still no specific legal protection of public servants reporting irregularities, some procedural measures protecting whistleblowers have been introduced. They will be held liable to disciplinary action only after the respective case is addressed at a meeting of the committees responsible for compliance with official conduct requirements and settlement of conflicts of interest. They are also entitled to free legal assistance if facing any kind of prosecution.

- Public officials have been obliged to declare their income since 2008. In recent years the requirements were tightened, requiring officials to disclose their financial assets and property as well as the income, assets and the property of their spouses and children. In the case of noncompliance, an official can be dismissed. A law adopted in 2012 obliges public officials to declare all expenditures on real estate vehicles and financial securities exceeding three-year family earnings. A separate new law requires senior officials and their close family members to close bank accounts abroad by September 2013 and repatriate financial assets to Russia. Officials who decide to keep their property abroad would have to resign. Public officials are also obliged to report all the gifts that they receive during the performance of their professional obligations.

- Obligatory rotation of civil servants was introduced in January 2013. This applies primarily to public officials exercising control and supervisory functions. The purpose is to prevent the occurrence of too close a relationship between officials and supervised entities. Hence, public officials are to change jobs every 3-5 years, with the specific period in a given job dependent on the associated corruption risk assessment. Changing posts is neither a disciplinary measure nor a reward, but officials are offered an option of additional vocational training and reimbursement of moving costs. Again, the refusal to move by an official would be treated as a resignation matter.

- Proposed rules on lobbying prepared by the Ministry of Economic Development are currently being considered by the Presidential Administration.

The new law on public procurement, adopted in April 2013, also addresses corruption. Public procurement involves a higher risk of corruption in all countries but this risk seems to be particularly high in Russia. According to the World Economic Forum (2013), favouritism to well-connected firms and individuals when deciding upon contracts and policies in Russia was evaluated at 2.4 on the scale of 1 to 7 (with 7 representing the best result). This compares unfavourably with the majority of OECD countries but also with China at 3.8, Brazil at 2.9 and India at 2.8. The new law addresses this problem by regulating and increasing transparency and openness at all stages of the procurement process, including forecasting and planning, new implementation of new purchasing procedures, contract performance, audit and control based on the evaluation of the final project results. More specifically, information about all the public tenders has to be published on the official procurement website. Tendering is organised in electronic form on five official electronic trading platforms. The business history, and qualifications and reputation of the bidders will be also checked. In the past, a company with no business history could win a tender by proposing dumping prices and subsequently failing the task. Such a situation provided opportunity for corruption and collusion. The new law foresees a "black list" of unfair providers being officially published by the Federal Antimonopoly Service. While this is a step in the right direction, the new law does not disqualify firms with past corruption offences. 
Another milestone was the ratification of the OECD Anti-Bribery Convention in January 2012, banning bribes to foreign officials. The Phase 1 evaluation report adopted by the OECD Working Group in March 2012 identified a number of challenges, especially a need to explicitly and clearly ensure the criminalisation for the "offer" and "promise" of a bribe, and to ensure that giving bribery to a third-party is also legally covered. The Phase 2 review by the OECD Working Group on Bribery in October 2013 revealed progress, but also urged that legislation and law enforcement be strengthened, with an awareness campaign against foreign bribery. In particular, Russia was praised for explicitly disallowing the tax deductibility of bribes to foreign public officials and for introducing the statutory requirement for companies in Russia to have anti-corruption measures in place. The report recommends that: $i$ ) the scope of foreign bribery offences should be expanded so that it applies to all of the cases covered by the OECD Anti-Bribery Convention; ii) the recently instituted framework for holding companies liable for foreign bribery should be extended; iii) law enforcement and related agencies should implement a proactive approach to detecting, investigating and prosecuting foreign bribery offences and related accounting offences; $i v$ ) measures should be introduced to allow for the seizure and confiscation of a bribe and its proceeds and to improve coordination and accountability among law enforcement authorities; and v) foreign bribery should have a higher profile in anti-corruption efforts. Russia's accession to the Convention will provide inspiration for additional measures to fight domestic corruption.

There were several other initiatives aimed at involving business in the fight against corruption. A working group headed by the Minister of Economic Development, which brings together the main business associations and public authorities, was established in October 2011 to develop anti-corruption measures in business and investment areas leading to the implementation of the Anti-Corruption Charter of Russian Business. The Charter combines international standards of business conduct with clear rules and procedures for admission, membership verification and the resolution of disputes regarding potential violations. A specialised centre "Business against Corruption" was also set up with substantial political backing to protect business representatives from corporate raiding and corruption pressures.

Importantly, legislative and regulatory changes were accompanied by stepped-up efforts at enforcement. According to the information from the Prosecutor General's office, the number of corruption cases brought to justice increased by $25 \%$ in 2012. A number of high-level corruption scandals were also revealed, including one involving a Minister of Defence. Another recent high-profile case was linked with fraud in the innovation centre Skolkovo. A number of cases have also been opened in connection with corruption and embezzlement in state corporations and public procurement. Corruption cases were also revealed in the implementation of contracts for the 2014 Sochi Winter Games.

It is difficult to assess to what extent the current surge in the fight against corruption will be effective. Russian society has yet to be convinced: $77 \%$ of Russians think government efforts are not effective (Transparency International, 2013). Moreover, some corruption cases are sometimes perceived as politically motivated. However, the latest compliance report of the Council of Europe's Group of States against Corruption (GRECO, 2012) concluded that Russia implemented as many as fifteen out of its 26 wide-ranging recommendations, with remaining eleven being partly implemented. The systemic character of actions combining a wide range of legislative and regulatory changes, a focus on transparency and disclosure and determined enforcement might finally make a difference, and send a powerful message about the increased risks of using public money for personal gain.

There is insufficient official enthusiasm to increase the role of civil society and media to publicise corruption scandals. A number of assaults against journalists who reported alleged corruption involving high level public officials remain unpunished. The perception of legal protection for whistleblowers is also undermined by the handling of a case of a whistleblower who died in custody and was recently sentenced posthumously, using rarely applied legal regulations. 
ECO/WKP(2015)10

Improving the rule of law is a challenge

Table 1. World Justice Project Rule of Law Index

Ranking among total of 97 countries

\begin{tabular}{|c|c|c|c|c|c|c|}
\hline & Russia & $\begin{array}{c}\text { Average } \\
\text { Western Europe } \\
\text { and North America }\end{array}$ & $\begin{array}{c}\text { Average } \\
\text { Eastern Europe } \\
\text { and Central Asia }\end{array}$ & Brazil & China & India \\
\hline Limited government powers & 92 & 12 & 57 & 35 & 86 & 37 \\
\hline Absence of corruption & 71 & 13 & 52 & 38 & 40 & 83 \\
\hline Order and security & 92 & 17 & 37 & 69 & 32 & 96 \\
\hline Fundamental rights & 83 & 12 & 45 & 33 & 94 & 64 \\
\hline Open government & 74 & 14 & 51 & 31 & 69 & 50 \\
\hline Regulatory enforcement & 68 & 14 & 51 & 37 & 80 & 79 \\
\hline Civil justice & 65 & 14 & 49 & 43 & 82 & 78 \\
\hline Criminal justice & 78 & 14 & 50 & 52 & 39 & 64 \\
\hline
\end{tabular}

Source: World Justice Project Rule of Law Index 2012.

One of the main determinants of the business climate is the strength of the rule of law, and the independence of the judiciary system in particular. Russia has remarkably weak rule of law, as illustrated by the World Justice Project index (Table 1). It performs poorly not only in comparison with OECD countries, but also with its regional and BRIC peers. Russia has a particularly poor ranking in terms of government powers being limited by law, judiciary and audit review, and possible sanctions for officials overstepping their duties. Fundamental rights appear to be very weakly protected, particularly because of problems with due process and improper government influence over the justice system. This is consistent with the revived use of the Soviet-era expression "telephone justice" signalling the widespread perception that public officials are able to influence judicial decisions (Ledeneva, 2011). As for the quality of justice, the state of civil justice seems more favourable than the criminal system. This is consistent with other evidence confirming progress in improving the efficiency and competence of the economic courts (World Bank, 2013).

The Russian authorities have taken a number of steps to strengthen the judicial system in recent years. The Federal programme "Development of the Judicial System 2007-12" focused on improving operational aspects, investing in modern infrastructure and technologies, including e-justice. Improvements are clearly visible. For example, ICT solutions enabled Russia's economic courts to simplify and shorten procedures, automate processes and publish decisions. As a result, the share of firms considering court administration as a major obstacle in their business activity fell from $21 \%$ in 2008 to $7 \%$ in 2011. It is more difficult to assess the impact on key aspects of the rule of law, such as independence. The newly adopted follow-up programme "Development of the Judicial System in 2013-20" focuses in turn on increasing the transparency, accessibility and openness of the judicial system. For example, the programme foresees audio-visual recordings of proceedings and broadcasting sessions on the Internet. It can therefore be hoped that the programme will improve the quality of rulings and increase social trust in the system.

Increasing the integrity of the judicial system is an essential condition for strengthening the rule of law. Several initiatives were directed at improving the pay and training of judges. The three-year trial period for judges was cancelled. A presidential decree of June 2012 increased judicial salaries and provided extra payments dependent on qualification and skills. Unfortunately, rotation of judges and randomised case assignments, recommended by the 2011 Economic Survey to prevent long-term informal 
relationships influencing legal decisions, have not been implemented. Greater transparency in appointment and promotion processes would also be an important step forward. The scope for discretion available to tribunal presidents, regarding for example housing allocation and the assignment of cases, has not been limited, though this could reduce the degree of influence that can be exerted on judges.

Several other changes in the judicial system are planned. The merger of the highest economic court with the Supreme Court of general jurisdiction is intended to eliminate the possibility of different interpretations of the same case in economic and general jurisdiction courts. This step needs to be implemented in a way that would avoid putting the perceived efficiency and independence of economic courts at risk. The State Duma is currently considering a draft law to establish administrative justice chambers in general jurisdiction courts and a new draft code on administrative court procedure, which should improve the ability of citizens to protect their rights against state action or inaction. Another initiative to improve the quality of judiciary decisions is the introduction of a new criminal appeals procedure.

It is also important to make law-enforcement agencies more transparent and accountable. Notably, senior prosecutors under Russian law may intervene in the prosecution process and review a decision to prosecute. While such interventions are often justifiable and necessary, the absence of clear guidance can create room for undue influence. The role of supervising prosecutors and procedures for distribution and re-distribution of cases among prosecutors raises similar concerns. In the case of the Investigative Committee, grounds for dismissal of the Chairman and his deputies are not clearly specified in the law, with the full discretion left to the Russia's President. This limits the necessary independence of an investigative agency.

In order to protect businesses from administrative and legal abuse by the government, the position of Federal Business Ombudsman was created in June 2012. The new office is headed by a former head of the nongovernmental organisation Delovaya Rossia (Business Russia). The work is supported by more than 60 regional ombudsmen working on a voluntary basis, as legislation requiring regional ombudsmen will come into force only in 2014. One of the first initiatives proposed by the Ombudsman, to increase the confidence of current and potential investors in the Russian judiciary system, was an amnesty for businessmen convicted for "swindling" (Article 159 of the Russian Criminal Code). In its originally proposed form, the amnesty would have affected about 110000 businessmen charged with economic crimes. However in its final narrower form (involving only 27 articles of the Criminal Code) adopted by the State Duma in July 2013, it is expected to affect only 10000 businessmen (or no more than 2000 businessmen according to different estimates) who were convicted for the first time for lesser economic crimes and who are ready to pay damages. The amnesty applies to those whose cases are still under investigation or have yet to be considered by the courts, which may be important for those in lengthy pre-trial detention. The implementation of the amnesty has been slower than expected, with some doubts about its real impact. The Human Rights Council proposed recently to prepare another amnesty coinciding with the 20th anniversary of the Russian Constitution for those convicted of non-violent crimes in the 1990s and 2000s.

In December 2012 a number of amendments were introduced in article 159 of the Russian Criminal Code on "swindling", as recommended in the previous OECD Economic Survey. The amendments include six new articles clarifying the types of swindling, which had been interpreted very broadly. Cases are to be initiated only after the complaint of a victim, which was not the case before. This marks important progress, because this article was often considered to be overused and its revisions can reduce legal uncertainty risks. Legal changes shortening the length of pre-trial detention are also needed. On the other hand, unanswered concerns of the Presidential Council on Human Rights on the validity of the second Khodorkovsky trial may lead to an impression of tolerance for predatory use of the law against business 
people. More recently the exodus of a prominent economist fearing to be prosecuted for his views as a member of the Presidential Council added to concerns about an uneven application of the law.

More broadly, interactions between politics, business and law enforcement generates a flow of troubling news, which might be contributing to large capital outflows and sluggish private investment (CNBC, 2013; FT, 2013). Notably, price/earnings (P/E) ratios, which in Russia are two to three times lower than in other BRICS countries, suggest a much higher risk than elsewhere.

Strengthening transparency, accountability and trust in public institutions would be supported by a stronger civil society. Recent progress in this area is mixed. On the one hand, there were several positive initiatives aimed at strengthening civil society participation:

- President Putin decreed that all legislative initiatives that had gathered 100000 signatures should be discussed by the State Duma. A Federal state system of E-democracy was accordingly established in Spring 2013 to pre-select initiatives and publish them on a dedicated portal.

- Since April 2013 all new laws and regulations are to be publicly discussed. An "E-parliament" system will soon allow parliamentary committee meetings to be watched on the internet. Stakeholder consultations were strengthened at all levels of the government. Improvement in the Regulatory Impact Assessment procedure and mechanisms of National Entrepreneurial Initiative (both described later in this chapter) give business representatives more structured opportunities to have their say when legislation is being drafted.

- A number of laws passed between 2009 and 2012 simplified the functioning of non-governmental organisations (NGOs) by facilitating registration, improving taxation and creating a Coordination Council on State Support of Charity in the Ministry of Economic Development. The Council distributes grants to NGOs, including those that have usually been critical of the current political leadership.

On the other hand, the new law on assembly puts in place much tighter restrictions on participation in public debate, including tighter regulation of participation in public protests. The law on NGOs that entered into force in November 2012 requires any NGO that is involved in broadly defined political activities (i.e. influencing public decision making and public opinion) and receives a foreign donation, independent of its amount, to register as a "foreign agent", a label that is highly stigmatising in Russia and carries the connotation of spying. The implementation of the law led to intrusive searches of hundreds of NGOs. Prosecutors have concluded that more than 200 NGOs should register as foreign agents, even though most of them stopped receiving foreign funding after the bill was passed. Almost every NGO has refused to register and several prominent NGOs announced they might close down. As of September 2013, only one NGO is registered as a foreign agent. While conducting searches, prosecutors also uncovered over 500 violations in the groups' activities, unrelated to the Foreign Agent Law. The law and its heavy-handed enforcement attracted criticism from UN, OSCE, the Council of Europe and several human rights groups.

The media are not becoming more independent. Reporters without borders' Press Freedom Index (2013) puts Russia at 148th place out of 179, in comparison with 142nd place in 2012. This evaluation is echoed by Freedom House (2012), which noticed a decrease in media diversity in 2012 as many media outlets have been purchased by or become dependent on the government. On the other hand, more than $50 \%$ of population had the access to the internet in 2012 and are potentially exposed to independent discussion, including popular anti-corruption blogs. 


\section{The role of the state in economy}

The state retains an unusually high stake in the Russian economy (Figure 2). This is mainly a legacy from the Soviet system, but it is also linked to the dependence on natural resource extraction and natural monopolies that often remain in state hands. State-owned enterprises (SOEs) account for about half of GDP and occupy a dominant position in a number of important sectors (Figure 3), including banking, transport and energy. The continued dominance of the largest SOEs, which seem to have privileged access to finance, has an important impact on the economy, as it complicates market entry and suffocates competition, while preserving pockets of inefficiency. Privatisation and improved corporate governance of SOEs are therefore essential for improving overall productivity.

\section{Figure 2. Product market regulation indicators: public ownership}

2008 , index scale of 0-6 from least to most restrictive

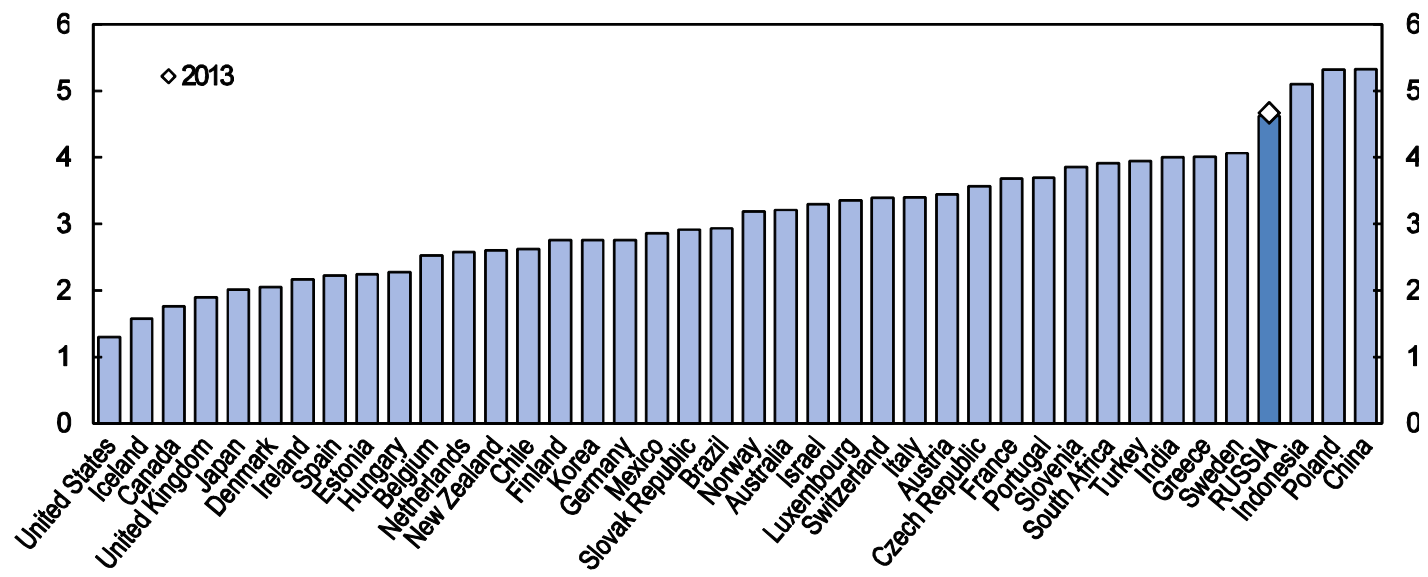

Note: The reference year is 2008 for all countries. The PMR indicator for Russia for 2013 is preliminary, and for purposes of comparability is calculated on the basis of the 2008 methodology. For more details, see the document prepared for discussions at the October 2013 meeting of the Working Party No. 1 of the Economic Policy Committee (ECO/CPE/WP1(2013)14). The document also provides the 2013 indicators with a revised methodology.

Source: OECD, "The 2013 Update of the OECD Product Market Regulation Indicators: Policy Insights for OECD and non-OECD Countries", ECO/CPE/WP1(2013)14.

Figure 3. State-owned enterprise shares among countries' top ten firms

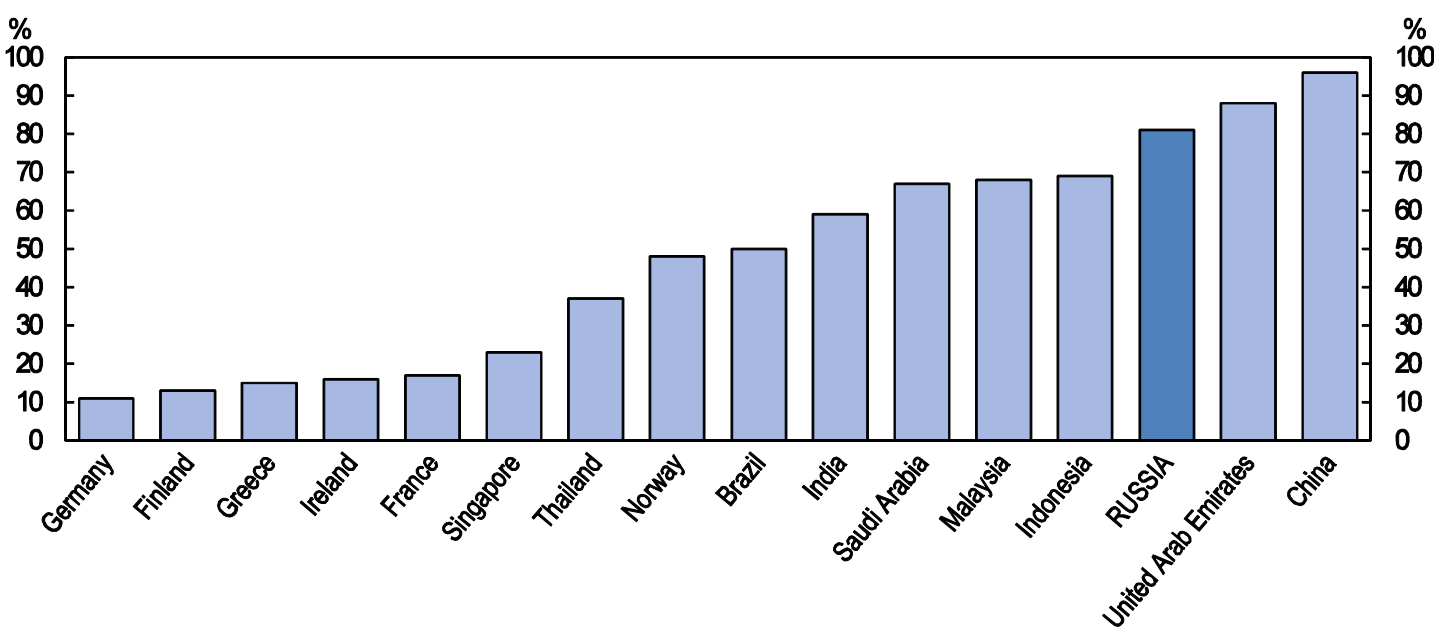

Note: Unweighted average of SOE shares of sales, assets and market values among country's top ten companies. It ranges from 0 (no state ownership) to 100 (all sales, assets and market value of country's ten largest companies are accounted for by SOEs). 
The privatisation plan for the years 2011-13 adopted in 2010 foresaw the privatisation of 1500 enterprises, including several large companies in key sectors, such as banking, energy, telecoms and transport. A presidential decree of May 2012 requests the full withdrawal of the state from all companies, except for natural monopolies and oil and defence sectors by 2016. The privatisation plan adopted by the government in June 2012 for years 2012-13 and the period until 2016 was also fairly ambitious. It foresaw full privatisation of large SOEs, such as VTB, Rosneft, Aeroflot, Rusgidro, Sheremetyevo airport and Sovkomflot, and a reduction of state ownership in RZD Russian Railways, Transneft and Zarubezhneft. However, the share of SOEs has actually grown in recent years, with important acquisitions by large SOEs which have outweighed realised privatisation deals. In particular, the state-owned oil company Rosneft purchased $100 \%$ of the privately owned TNK-BP, which made Rosneft the world's largest publicly traded oil company in terms of extraction and reserves, even though the government share in Rosneft declined as a result of this transaction. In the banking sector, VTB acquired a majority share in the Bank of Moscow.

Many smaller companies were privatised and large number of state stakes were sold, so that the number of state stakes in unitary enterprises has gone down from around 3500 to 1800 since 2010 and the number of stakes in joint stock companies has gone down from 3000 to 2300 in the same period. More than 1800 SOEs are scheduled for full or partial privatisation, including 638 unitary enterprises and 1201 joint stock companies. However, privatisation of large enterprises has been disappointing. The biggest transactions included the welcome sale of $7.6 \%$ of shares of Sberbank and $50.1 \%$ of United Grain Company that constituted about $80 \%$ of the income of the government from privatisation in 2012. New shares sold by VTB in 2013 to foreign sovereign funds reduced the government's stake in this bank from $75.5 \%$ to $60.9 \%$. But the majority of large privatisation transactions were delayed. According to official sources, the delays were due to unfavourable market conditions, but Prime Minister Medvedev publicly mentioned the lobbying by "individual ministers and officials" against transactions "that would take away their control over a set of assets" as a barrier to privatisation.

While the reluctance to sell state assets below fair value is understandable, there is a risk that attitudes are turning against privatisation. This hypothesis is corroborated by a substantially more modest privatisation plan for 2014-16 announced in the summer of 2013 (Table 2). Among the main changes is the decision to retain VTB, Rosneft, Rusgidro and Zarubezhneft under state control until at least 2016. Further partial privatisation of Sberbank within the planning period was also ruled out. It remains to be seen to what extent the new and more modest plan will be implemented more successfully than the last. 
ECO/WKP(2015)10

Table 2. Privatisation plan 2012-13 and until 2016 vs. privatisation plan 2014-16

\begin{tabular}{lccc}
\hline \multicolumn{1}{c}{ Company } & $\begin{array}{c}\text { State share in } \\
\text { September 2013 }\end{array}$ & $\begin{array}{c}\text { Target state share } \\
\text { under privatisation plan } \\
\mathbf{2 0 1 2 - 1 3} \text { and until 2016 }\end{array}$ & $\begin{array}{c}\text { Target state share } \\
\text { under privatisation plan } \\
\mathbf{2 0 1 4 - 1 6}\end{array}$ \\
\hline Rosselkhozbank & $100.0 \%$ & Full exit by 2016 & No plans for privatisation \\
\hline Sberbank & $50 \%+1$ & $50 \%+1$ (reduction from 57.6\%) & No plans for privatisation \\
\hline VTB & $60.9 \%$ & Full exit by 2016 & $50 \%+1$ \\
\hline Rostelecom & $55.6 \%$ & Full exit by 2013 & Full exit by 2016 \\
\hline Aeroflot & $51.2 \%$ & Full exit by 2016 & $25 \%+1^{*}$ \\
\hline RZD Russian Railways & $100 \%$ & $75 \%+1$ & $75 \%+1$ \\
\hline Sovkomflot & $100 \%$ & $25 \%+1$ & $25 \%+1$ \\
\hline Sheremetyevo airport & $83.0 \%$ & Full exit by 2016 & Full exit by 2016 \\
\hline Vnukovo airport & $74.7 \%$ & - & Full exit by 2016 \\
\hline Rusgidro & $67 \%$ & Full exit by 2016 & $50 \%+1$ \\
\hline Rosneft & $69.5 \%$ & Full exit by 2016 & $50 \%+1$ \\
\hline Transneft & $78.3 \%$ & $75 \%+1$ & $75 \%+1$ \\
\hline Zarubezhneft & $100 \%$ & Full exit by 2016 & $50 \%+1$ share \\
\hline
\end{tabular}

* Probably full exit from the capital after 2016.

Source: Ministry of Economic Development, Vedomosti.

Given the delay in privatisation and the fact that not all state companies can be privatised, improvement in the governance of the SOEs is a key challenge. The simplification of the SOE ownership models would be a step forward, as currently the sector is characterised by many different types of enterprises which reduces transparency regarding state ownership and accountability. It also complicates the regulatory framework and the unbundling of the commercial and non-commercial roles of SOEs. A harmonised management model respecting competitive neutrality, in line with the OECD Guidelines on Corporate Governance of State-Owned Enterprises, could help to address these problems. The authorities are currently planning to streamline the sector by introducing the joint stock company as a dominant model for all SOEs with commercial objectives and a new "public law legal entity" for SOEs with public function objectives, while significantly reducing the number of state unitary enterprises by 2016 . This would be positive move forward, but so far progress in actual reorganisations is slow. The Russian authorities also plan to develop specific company goals to address any non-commercial objectives and public policy obligations, which would improve transparency of SOE operations. Nevertheless, the remaining "special list" of companies beyond the control of Rosimushchestvo and with direct links to executive powers remains a challenge in this respect. It is also important to improve the protection of minority shareholders in SOEs.

The autonomy of directors is an important determinant of the quality of governance of SOEs. The decision to withdraw top level public officials from the management of state companies by September 2015 was therefore a move in the right direction. A number of SOEs (RZD, VTB, Rosneft, and Gazprom) already replaced old directors with professional ones, but otherwise the process is rather slow and should be accelerated. Moreover, the "system of instructions", under which some state-appointed directors are still required to vote at SOE board meetings according to the state's preferences on a number of issues, should be reconsidered in the spirit of compliance with OECD Guidelines. 
The introduction of a special committee for the selection of directors and the implementation of performance-related remuneration can contribute to the independence of SOE management. To improve the efficiency of state holdings, special committees on labour, auditing and strategic planning were also introduced. Key Performance Indicators are also set for such companies. One example is the centrally adopted target of achieving 10\% cost savings during the next two years. Committees are also monitoring decisions about divesting non-core activities and stimulate cooperation with SMEs. These changes are positive in limiting direct political influence over SOE activities. Monitoring results are shown online on the webpage of Rosimushchestvo, which contributes to transparency.

However, most of the largest listed SOEs are traded on the lowest listing levels of the Moscow Stock Exchange, where corporate government requirements oblige them to disclose little information about the company structure and activity. Gazprom and some other companies are traded "off listing" which reduces these requirements even further. The quality of governance in SOEs could therefore also be improved by obliging them to increase the level of their stock exchange listing. It seems that the authorities consider moving in this direction, and also develop a plan to list all SOEs by 2018.

\section{Reforms addressing administrative burden are showing results}

SME development in Russia is lagging behind OECD countries, as well as other transition and emerging economies. SMEs account for only $25 \%$ of Russian employment, compared to $50 \%$ on average in OECD countries and Russian SMEs similarly lag behind in terms of production, exports and innovation (OECD, 2014). The dominant role of large state-owned enterprises, the poor business climate and poor access to financing are most likely the main explanation of this poor performance. They interact with negative attitudes towards entrepreneurship, as only $2 \%$ of people consider starting their own business in Russia in comparison with $26 \%$ in the countries with comparable income, putting Russia at the last spot among 69 countries reviewed by the latest Global Entrepreneurship Monitor (GEM, 2012).

In order to address the administrative impediments to small business development, the National Entrepreneurial Initiative "Improvement of Business Climate" was initiated at the end of 2011. The ranking of Russia in the World Bank Doing Business project was adopted as one of the main measures of programme success. The goal is to put Russia in the top twenty by 2018 with the mid-term goal of reaching 50th place in 2015. The Initiative introduced 13 roadmaps, addressing the most important weaknesses, including business registration, construction permits, access to the electricity grid, property registration, development of competition, access of SMEs to public procurement and improvement of the quality of the regulatory environment for business. The roadmaps were prepared by the Agency for Strategic Initiatives (ASI) and had been closely discussed between businessmen and public officials. The private sector also plays a crucial role in monitoring results. Work on preparing 10 roadmaps has finished and the process of implementation in pilot regions has already started to achieve some promising results. The early success of the project is witnessed by the fact that Russia was named one of the top three reformers in the 2014 Doing Business ranking, with the overall rank improved to 92nd from 120th in 2011.

Much progress has been achieved in reducing the administrative barriers to SMEs, Russia having recently improved its World Bank Doing Business rank in terms of the overall ease of opening business from 111th in 2011 to 88th. Starting a new business is relatively cheap compared with high income OECD countries. The introduction of one-stop shops has made the process of firm registration more efficient, and procedures to open a company bank account have been simplified. The 2011 law on licencing has substantially decreased the number of licensed activities, made licence duration indefinite and simplified procedures. However, changes have stopped short of introducing a "deemed clearance" principle as recommended in the previous Economic Survey of Russia. Claims for exemption from VAT have been streamlined. The Ministry of Economic Development continues to work on simplifying the registration process for legal entities and sole proprietors. Preliminary Product Market Regulation index calculations 
for 2013 confirm substantial progress in the area of reducing administrative burdens for business start-ups over the last 5 years (Figure 4). Also a much lower share of firms reported that licensing, tax and court administration processes were significant obstacles to their business in 2011 compared to 2008 (World Bank, 2013).

Figure 4. Product market regulation indicator: barriers to start-ups

2008, index scale of 0-6 from least to most restrictive

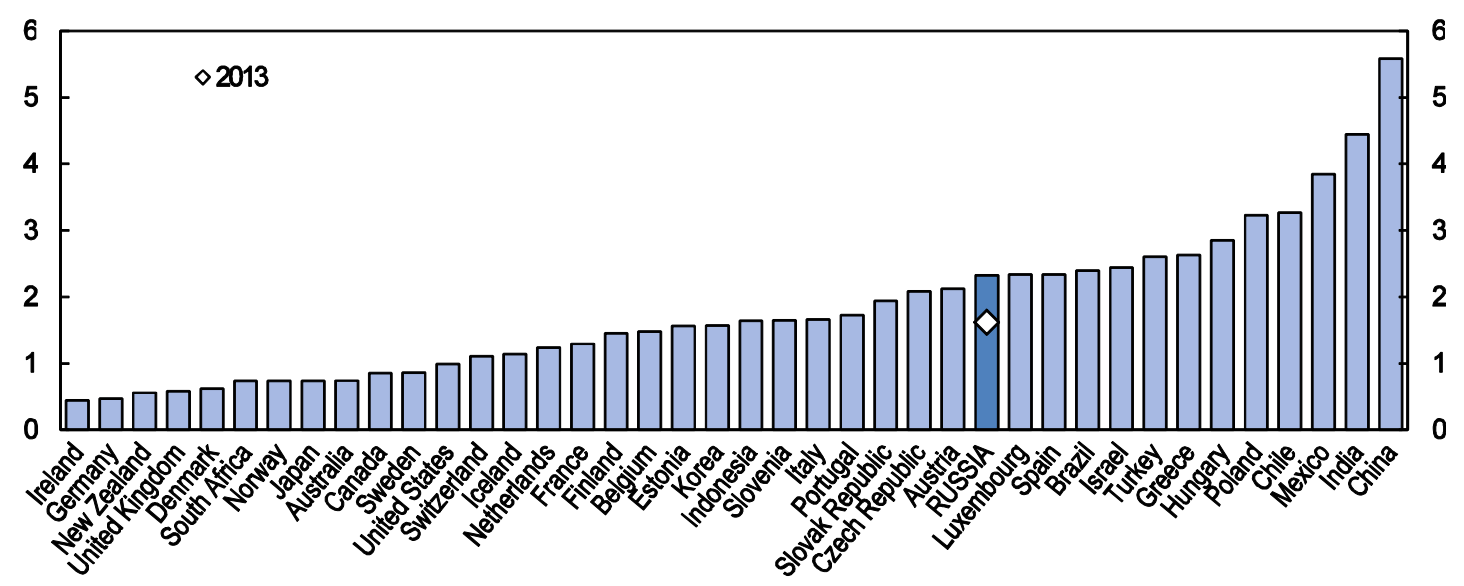

Note: The reference year is 2008 for all countries. The PMR indicator for Russia for 2013 is preliminary, and for purposes of comparability is calculated on the basis of the 2008 methodology. For more details, see the document prepared for discussions at the October 2013 meeting of the Working Party No. 1 of the Economic Policy Committee ECO/CPE/WP1(2013)14. The document also provides the 2013 indicators with a revised methodology.

Source: OECD, "The 2013 Update of the OECD Product Market Regulation Indicators: Policy Insights for OECD and non-OECD Countries", ECO/CPE/WP1(2013)14.

Other serious problems have also been addressed. According to the 2014 World Bank Doing Business report, dealing with construction permits was made easier by eliminating several requirements for project approvals and reducing new building registration time. Getting electricity was made simpler and less costly by setting standard connection tariffs and eliminating many procedures. Transferring property was also made easier by streamlining procedures and introducing time limits for processing applications. However, there is still considerable scope for improvement: dealing with construction permits takes 297 days compared with 26 days in Singapore, obtaining electricity 162 days compared with 17 days in Germany, registering property 22 days compared with 1 day in New Zealand.

Another activity of the ASI is the preparation and implementation of a Regional Investment Standard that aims to codify best practices and hence make the relationship between business and the state more transparent and efficient, and hence to increase investment in the regions. In 2012 the Standard was implemented in 13 regions and tested in another 6 regions, whereas in becomes obligatory in all 83 regions in 2013. Perhaps most interestingly, surveys of entrepreneurs were adopted as Key Performance Indicators (KPI) assigned to the regional authorities, contributing to systematic assessment and benchmarking of their performance.

An institutional process to minimise the regulatory burden on business is essential. A regulatory impact assessment (RIA) procedure was introduced in 2010 and implementation picked up speed after 2011. All government draft acts dealing with regulation are routinely sent to the RIA department of MED, which has performed more than 1800 assessments, and around $35 \%$ of them identified problems that required changes in the law. A preliminary assessment takes 5 days. If it finds that a given regulation could potentially have a negative influence on the business environment, a more detailed cost and benefit study is 
carried out within one month. The full assessment includes public hearings. Progressively, existing government laws and regulations are also being screened.

Additional amendments have been adopted recently to further strengthen RIA. According to a presidential decree from 1 July 2013, regulatory impact assessments will now be started at a very early stage by institutions originating a draft law and regulation, long before it is being sent to the RIA department at MED for final verification. Consultations with key stakeholders will also be enhanced at every stage of draft preparation. Although a negative RIA assessment does not constitute a veto, and its recommendations are non-binding, practice so far confirms a high level of compliance. Such comprehensive RIA procedure is likely to have a significant impact on the quality of regulation, which would be further strengthened when the planned on-going RIA is finally introduced.

A presidential decree from 2012 provides for RIA at the regional level from 2014 and municipal level from 2015. This is an important step forward as many barriers to business entrepreneurship originate at these levels (EBRD, 2012). A number of regions are already participating in pilot RIA. A consultative council was established to strengthen cooperation with regions, improve monitoring and transfer know-how. This work is supported by regular workshops, as building capacity for conducting RIA at the sub-national levels and in specific line ministries is critical. RIA will be expanded to the law on customs and tax issues. It will be done as well for the Customs Union laws, generated by Belarus and Kazakhstan.

To involve the State Duma in the process, a newly passed law empowers the Duma to demand a review of the draft on an ad hoc basis. But the remit of RIA could be extended to systematically reviewing legislative changes considered by the Duma.

\section{Competition policy should become a cornerstone of structural policies}

Competition in Russia is still hampered by the dominance of large state-owned enterprises and barriers to foreign trade and investment, problems which are confirmed in the latest results of the OECD Product Market Regulation Indicator (Figure 5).

The role of competition protection policy lies in preventing abuses of a dominant market position. The Federal Antimonopoly Agency (FAS) is a strong institution with a solid track record of effective competition rule enforcement. It also has also strong public outreach and capacity building programmes implemented through specialised university programmes. The recently introduced "Third anti-monopoly package" strengthened the competition policy framework by introducing a "prevention" instrument to decrease the number of cases concerning small repetitive abuse of dominance. This is an important change as FAS seemed to be overwhelmed with many insignificant cases.

One problem in effective competition policy enforcement is insufficient conformity between the competition law and the criminal code, so the recent introduction of a harmonised definition of a cartel is a major achievement. In turn, clarification of the determination of a monopolistically high price is an important step in further improving the quality and relevance of economic analysis of competition issues, which again should allow better prioritising of resources on the most important threats to competition. On a less positive note, the September 2012 presidential decree obliged Gazprom and other strategic Russian companies to get prior permission before providing information to the foreign competition authorities, raising concerns about the extent of commitment to international cooperation in competition policy matters. 
Figure 5. Product market regulation indicator: barriers to trade and investment

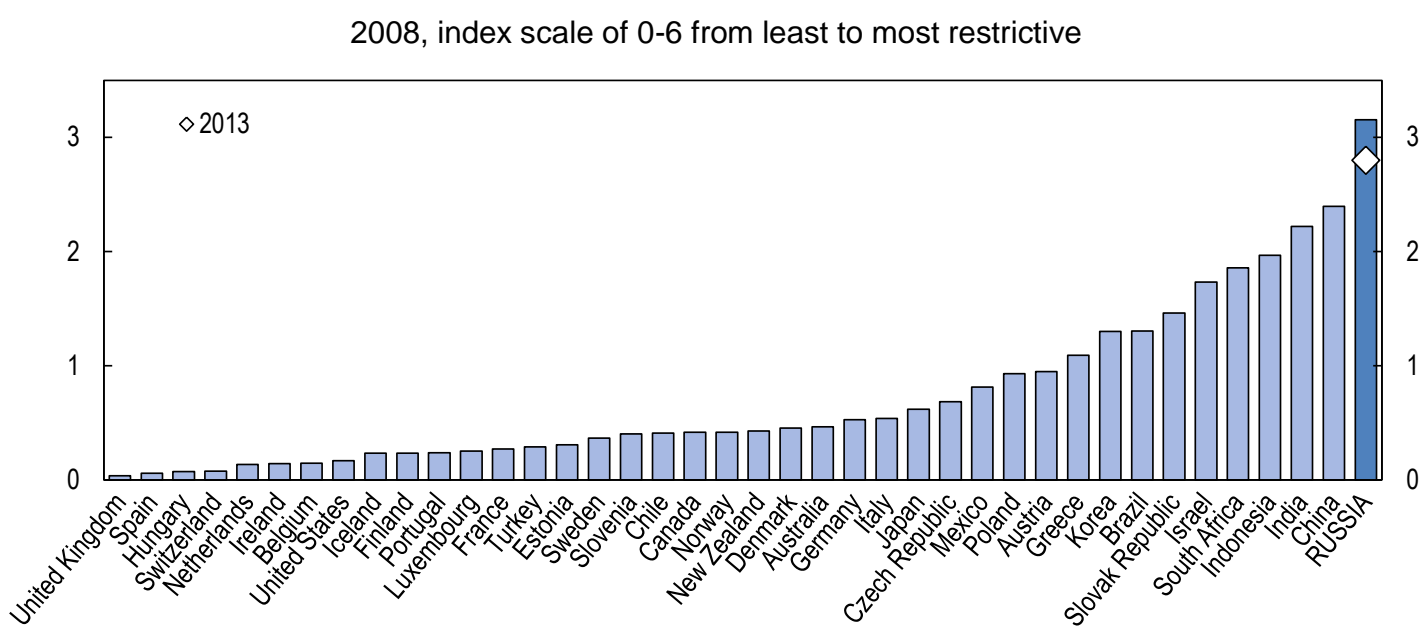

Note: The reference year is 2008 for all countries. The PMR indicator for Russia for 2013 is preliminary, and for purposes of comparability is calculated on the basis of the 2008 methodology. For more details, see the document prepared for discussions at the October 2013 meeting of the Working Party No. 1 of the Economic Policy Committee (ECO/CPE/WP1(2013)14). The document also provides the 2013 indicators with a revised methodology.

Source: OECD, "The 2013 Update of the OECD Product Market Regulation Indicators: Policy Insights for OECD and non-OECD Countries", ECO/CPE/WP1(2013)14.

Broader challenges to competition policy were addressed in a roadmap on "Development of Competition" prepared as part of the National Entrepreneurial Initiative. In this roadmap, an explicit priority is given to reducing the role of the state in the economy. In particular, a draft "fourth antimonopoly package" currently being considered by the State Duma would restrict the establishment of new state owned enterprises, especially on regional and local levels, and require explicit permission by FAS based on its assessment of the competitive situation in a given market. In the future, FAS will also systematically review the operation of existing SOEs with the presumption that in many instances the current state of market development does not necessitate state intervention in the form of an SOE. Establishing clear "rules of the game" regarding competition policy is to be facilitated by the creation of a special body in FAS, which is authorized to give official explanations regarding the practice of competition law. Secondly, the importance of the whole-of-the government approach is recognised, resulting in a recent resolution that defines, for the very first time, competition promotion as a task shared across all government institutions. Also a link between SME promotion and competition policies is now reflected in the structure of the Ministry of Economic Development, which is responsible for policy development in both these areas.

Finally, the roadmap marks a shift from top-down policy making towards intensifying dialogue with business. The roadmap was developed by a working group, which was headed by the business organisation Delovaya Rossia with the participation of the government. The business sector will also play a leading role in monitoring implementation.

\section{WTO membership is an opportunity to promote competition}

WTO accession in 2012 was expected to deepen Russia's integration into the global economy and contribute to improving the regulatory culture. By joining the WTO, Russia committed to adhere to multilateral rules that ban the arbitrary use of protectionist and discriminatory trade-distorting practices. After the phase-in period, Russia's average bound tariff will be reduced from $11.9 \%$ to $7.1 \%$ (which is still above the average bound tariff in OECD countries). Among other commitments, access will be liberalised in such service sectors as telecommunications, insurance, transport and distribution. The World Bank has 
estimated the short-term welfare impact of the accession at 3.3\% of GDP, and a long-term impact at $11 \%$ with most of the gains stemming from the removal of barriers to FDI flows, in particular through services liberalisation (Table 3). However, most Russian businesses reported that WTO accession had had no impact on the Russian economy in 2013 (Strategy Partners Group, 2013) and the Russian Accounts Chamber expressed concerns about not making full use of the opportunities in connection with membership (RAC, 2013). Relations with key trading partners also remain difficult.

Table 3. Impact of WTO accession on economy-wide variables in Russia

\begin{tabular}{|c|c|c|c|c|c|}
\hline & \multicolumn{3}{|c|}{ Short-to-medium term effect } & \multirow[b]{2}{*}{ Total } & \multirow[t]{2}{*}{$\begin{array}{l}\text { Long-term } \\
\text { (steady state) }\end{array}$} \\
\hline & $\begin{array}{l}\text { Tariff reform } \\
\text { only }\end{array}$ & $\begin{array}{l}\text { Improved market } \\
\text { access only }\end{array}$ & $\begin{array}{l}\text { Reform of FDI } \\
\text { barriers only }\end{array}$ & & \\
\hline $\begin{array}{l}\text { Aggregate welfare } \\
\text { (\% of GDP) }\end{array}$ & 0.6 & 0.3 & 2.4 & 3.3 & 11.0 \\
\hline $\begin{array}{l}\text { Unskilled labour wage } \\
\text { (\% change) }\end{array}$ & 0.4 & 0.1 & 1.9 & 2.5 & 13.2 \\
\hline $\begin{array}{l}\text { Skilled labour wage } \\
\text { (\% change) }\end{array}$ & 1.5 & 0.6 & 2.5 & 4.7 & 17.6 \\
\hline
\end{tabular}

Source: Tarr (2007).

In part, the positive impact is simply delayed because of long transitional arrangements, under which tariff reduction is phased in until 2020. The longest transitional periods cover agriculture, automotive and civil aircraft industries. Russia negotiated long transition periods to help its most vulnerable sectors strengthen competitiveness through time consuming restructuring efforts. There is, however, a risk that such extended transition periods will reduce the incentives for business in shielded sectors to implement competitiveness-oriented changes. Such risks should be minimised by energetic competition policy enforcement and improved governance of state owned enterprises, as discussed above.

While Russia's trade is now governed by WTO rules, some potentially protectionist measures recently introduced by the government have raised concerns about Russia's compliance with its WTO commitments and have posed new obstacles to foreign trade. For instance, at a time when liberalisation of the trade regime would have been expected, Russia introduced a recycling fee on imported vehicles and food-safety related restrictions on certain agricultural and food products. These measures have been heavily criticised by its trading partners. The recycling fee has been viewed by partners as a discriminatory measure because only domestic manufacturers and producers in Kazakhstan and Belarus could obtain exemptions. A federal law on equalisation of conditions governing the payment of recycling fees was signed by the President in October 2013 and will come into force 1 January 2014. Nevertheless, the EU requested that an arbitration panel be established at the WTO Dispute Settlement Body, contesting the elements of the recycling fee. While the outcome of this case is still pending, it would be better for Russia to focus more on policies making the most of WTO accession.

Following WTO accession, Russia's sanitary and phyto-sanitary (SPS) policies need to comply with the requirements of the WTO SPS Agreement. However, Russia's SPS measures seem more stringent than international regulations with a negative impact on trade (US Trade Representative, 2013). While ensuring food safety is an evident priority for every government, Russia should explore the scope for deeper harmonisation of its SPS measures with international standards.

Another challenge is the full adaptation of domestic legislation and procedures to WTO operations (RAC, 2013). Out of 66 measures in the post-accession action plan, only 26 have been fully implemented 
to date. On the federal level, the authorities do not monitor the post-accession compliance in regions, and most regions do not have proper regulations to govern their economic activities in line with WTO rules. Improving administrative capacity to monitor and enforce compliance is therefore a key recommendation for speeding up the positive effects of accession. The government is understaffed in terms of skills relevant to the understanding and handling of WTO disputes. Opening a permanent WTO delegation could therefore be helpful.

Non-tariff barriers to trade also remain high. In particular, Russia's border administration has been assessed as persistently inefficient, with customs clearance processes ranked as 127 th out of 132 reviewed economies by the World Economic Forum's Enabling Trade Index in 2012. According to World Bank (2013), the "Trading across borders" rank for Russia is 157 among 189 countries. The cost of exports per container in Russia in 2012 was almost twice as much as in an average OECD member country. Until recently, progress has been rather modest. For instance, the authorities introduced an electronic customs system in 2008, but it did not replace the paper document flow, minimising actual gains. Also the electronic system implemented in Russia did not match internationally adopted standards and was not compatible with corresponding systems overseas (Korostelev, 2012). However, the federal reform road maps discussed earlier paid very high attention to these problems and progress has been visible more recently. According to the 2014 World Bank Doing Business report trading across borders was made easier by effectively implementing an electronic system for submitting export and import documents and by reducing the number of inspections. According to the Federal Customs Service, the time taken for customs operations at road border crossings decreased from 80 to 40 minutes between 2011 and 2013, and the time to import a container was reduced from 36 to 21 days.

All foreign goods are subject to national treatment provisions embedded in WTO Agreements, but in government procurement such provisions are afforded on a reciprocal basis. Russia did not sign the WTO Government Procurement Agreement (GPA), which governs rules for public procurement for many members, but announced its intention to initiate negotiations for membership of the GPA within 4 years. So, for the time being Russia has preserved the right to restrict the access of foreign companies to its growing public procurement market (estimated in 2012 at around 14\% of GDP). While, recent revisions of the legislation have moved public procurement towards greater transparency and thus in the direction of the GPA provisions, they have also broadened the range of reasons for the government to prohibit or limit admittance of foreign goods, works and services in the public procurement. They now include protection of the Russian domestic market, development of the national economy and support of domestic producers. In practice, public procurement tenders can include conditions for the preferential treatment of products of Russian origin in accordance with temporary provisions that introduce localisation incentives. Guidelines for procurement procedures for SOEs remain to be finalised. It is important for gains from trade that actual implementation of new and planned legislation does not create new barriers for foreign suppliers.

Another area of concern is compliance with WTO rules on trade-related intellectual property rights (IPR). Harmonisation of Russian IPR legislation with international principles is an important achievement. However, despite Russia's continuing efforts to improve its IPR regime, the implementation and enforcement of IPRs has long been a concern of Russia's trading partners. In 2013, a specialised court for intellectual property rights was established within the system of economic courts in Russia to deal with cases regarding patent rights, trademark violations and other intellectual property disputes. However, according to the Global Intellectual Property Center, Russia is among those countries with the poorest intellectual property rights protection (US Chamber of Commerce, 2013). Stepping up enforcement and fighting intellectual property rights violations more vigorously is therefore a priority.

Regional integration initiatives, if properly designed, may also strengthen competition and international value chains. They can also increase the scope and opportunities for wider integration. The Eurasian Customs Union (ECU), the latest Russian-led initiative in the region, appears deeper than 
previous initiatives, which did not achieve the expected results: the new ECU has a stronger institutional framework and its bodies have an obligation towards Russia to ensure that ECU measures are consistent with relevant WTO commitments. But long-term gains from the ECU will depend not only on the elimination of classic trade barriers but also the harmonisation of the regulatory measures and standards, which can otherwise increase costs and place unnecessary obstacles in the way of business. In this process, Russia must juggle national development objectives, ECU obligations and the requirements of the global WTO-based trading environment.

\section{FDI potential is not fully used}

Russia is relatively successful in attracting FDI with inflows of $1.6 \%$ of GDP in 2012, close to the OECD average. However, this figure is inflated because over $60 \%$ of reported FDI is the result of "roundtripping", with Russian owners structuring firms as an international conglomerate. Round-trip investment generally flows to regions with large endowments of natural resources and a high perception of corruption, and it is usually viewed as a response to institutional constraints in Russia, such as weak regulatory policies and shaky financial markets. There is also evidence that round-trip investment is less technologically advanced than genuine FDI (Ledyaeva et al., 2013), lowering its impact on economic development and regional convergence (Gonchar and Marek, 2013).

Attraction and support of FDI is a stated government priority and steps to improve the FDI climate have been taken at both the federal and regional levels. Several incentives are available to foreign investors, including budgetary support. In 2011, the Russian Direct Investment Fund was established by the government to operate with long-term foreign investors. The Fund is mandated to secure coinvestment, thus acting as a catalyst for foreign investment. The Fund has formed partnerships with financial institutions in 6 countries and has become an anchor investor for a large number of investment projects. Projects with a total value of more than USD 2 billion are already being implemented and projects worth another USD 9 billion are under considerations. Vnesheconombank, a state-owned bank, is another source of capital for investment projects that are available to foreigners. The bank already participates in the capital of companies, provides loans, credits, leasing facilities and guarantees for investment projects, and currently the government considers authorising the bank to administer infrastructure projects with funds from the National Welfare Fund.

However, these efforts cannot compensate for important and distorting barriers to FDI. Apart from the problems of the general business climate discussed above, the regulatory regime for FDI in Russia is more restrictive than in most OECD countries (Figure 6). Barriers to FDI remain unusually high in the financial sector, mining, transport, business services and real estate (OECD, 2012). Quotas and limitations on the scope of operations for licences granted to foreign investors in financial services are examples of particularly strict barriers. The share of non-residents in the authorised capital of Russian credit institutions was $27.5 \%$ in July 2013 , compared with the $50 \%$ quota and the share of controlled assets of $17.2 \%$. The removal of the application of reciprocity in the Banking Law for all OECD investors in October 2013 was an important step. While the reciprocity provision had never been applied, its removal provides valuable reassurance to potential investors, and expresses commitment to the principle of non-discrimination.

The Law on Enterprises Strategic for Defence and Security subjects to prior approval any transaction that would grant a foreign investor a majority interest, or effective managerial control, in an enterprise strategic for defence and security. It requires prior notification to the authorities of any transaction by a foreign investor leading to the acquisition of a majority interest or effective managerial control in any enterprise strategic for national defence and security. The threshold for prior notification is lower in mining enterprises which operate on "plots of federal importance", and in cases where the investing entities are controlled by foreign states. The authorities should continue to amend the law to simplify and improve the transparency of the application process and shorten the list of strategic. The Government Commission for 
Control over Foreign Investment, which grants approvals, should also regularly report to the State Duma to improve accountability.

Information on rules and procedures is still difficult to obtain for foreign investors and is spread across many sources, adding unnecessary costs to investing in Russia. In this regard, the principle of transparency in the OECD Codes of Liberalisation and National Treatment calls for improving access to Russian laws and regulations for foreign investors by providing foreign language translations and easing access to information by developing a dedicated and continuously updated internet site. The reform road maps, described in earlier sections, which aim at improving the business climate in critical areas such as customs, construction and public procurement have the potential to bring positive changes too. More transparent and accountable information practices, especially in regions that so far have been less successful in attracting foreign investors, are likely to facilitate foreign investors' operations and reduce their risks. 
Figure 6. FDI regulatory restrictiveness index

2012, index scale of 0-1 from least to most restrictive

\section{A. International comparison}

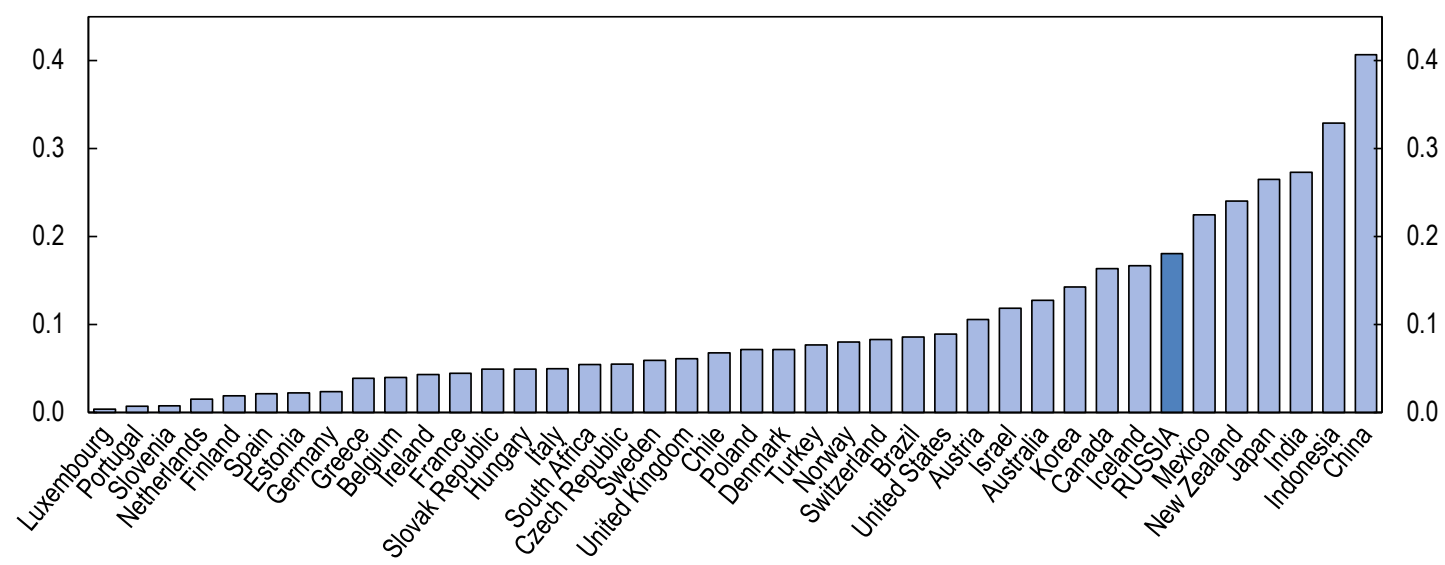

B. Russia, breakdown by sector

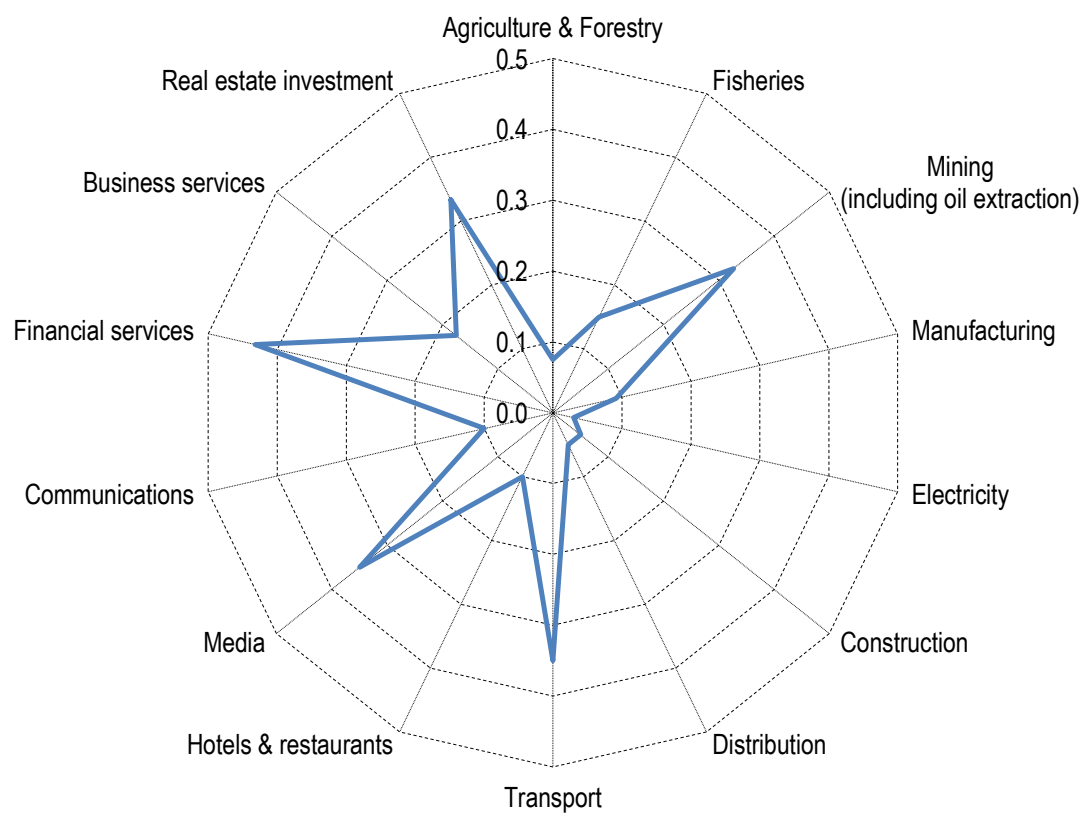

Note: A higher score of the Index indicates more restrictive regulations for FDI.

Source: OECD, FDI Regulatory Restrictiveness Index database. 


\section{Box 1. Recommendations for establishing a favourable business climate}

- Continue the current anti-corruption campaign with stronger focus on transparency and accountability mechanisms in the public sector. Improve legal protection of whistleblowers and do not restrict the scope for media or civil society organisations to publicise violations of the law.

- Strengthen judicial independence through greater transparency in appointment and promotion processes, better pay and rotation of judges, while providing better protection against outside interference in court cases. Make law enforcement agencies more transparent and accountable.

- $\quad$ Continue reducing administrative burden, and widen federal initiatives to regional and local levels. Extend regulatory impact assessments to legislative draft considered by the State Duma.

- $\quad$ Push ahead with privatisation of state-owned enterprises (SOEs), and large banks in particular. Further improve governance of SOEs and foster a level playing field between public and private companies.

- To strengthen the impact of WTO accession on competition, refrain from introducing entry barriers.

- Shorten the list of strategic sectors with prior approval required for foreign investment and streamline the approval process. The usefulness of quotas and limitations on the scope of operations for licences granted to foreign investors in financial services should be regularly examined.

\section{Bibliography}

CNBC (2013), Is Russia Too Corrupt for International Business?, 11 June, www.cnbc.com/id/100805382.

EBRD (2012), Diversifying Russia. Harnessing regional diversity, European Bank for Reconstruction and Development, London.

Freedom House (2012), "Freedom of the Press 2013: Russia".

FT (2013), "Alexei Navalny verdict sends ripples through Moscow business world", Financial Times, 18 July, www.ft.com/intl/cms/s/0/d2da85de-efb5-11e2-8229-00144feabdc0.html .

GEM (2012), GEM 2012 Global Report, Global Entrepreneurship Monitor.

Gonchar, K. and P. Marek (2013), Natural-resource or Market-seeking FDI in Russia? An Empirical Study of Locational Factors Affecting the Regional Distribution of FDI Entries, Higher School of Economics, Moscow.

GRECO (2012), Joint First and Second Evaluation Round, Addendum to the Compliance Report on the Russian Federation, Group of States against Corruption, Council of Europe, adopted by GRECO at its 58th Plenary Meeting, Strasbourg, 3-7 December 2012.

Gupta, S., H. Davoodi and R. Alonso-Terme (2002), "Does corruption affect income inequality and poverty?", Economics of Governance, March 2002, Vol. 3, Issue 1. 
ICD (2013), Survey of public opinion, Institute of Contemporary Development.

Kowalski, P. et al. (2013), "State-Owned Enterprises: Trade Effects and Policy Implications", Trade Policy Papers, No. 147, OECD Publishing.

Ledeneva, A. (2011), “Telephone Justice in Russia”, The EU-Russia Centre Review, Issue 18, May 2011.

Ledyaeva, S., P. Karhunen and J. Whalley (2013), "If Foreign Investment Is not Foreign: Round-Trip Versus Genuine Foreign Investment in Russia", CEPII Working Papers, February 2013.

Lehmann, H. and M. Silvagni (2013), "Is There Convergence of Russia's Regions?: Exploring the Empirical Evidence: 1995-2010", Economics Department Working Papers, No. 1083, OECD Publishing, doi: 10.1787/5k422105ht33-en.

Mauro, P. (1995), “Corruption and growth”, Quarterly Journal of Economics, Vol. 110 (3).

Mauro, P. (1997), "The Effects of Corruption on Growth, Investment, and Government Expenditure: A Cross-Country Analysis," in Elliot, Kimberly Ann (ed.), Corruption and the Global Economy, Institute for International Economics, Washington, DC.

Mobolaji, H.I. and K.Omoteso (2009) "Corruption and Economic Growth in Some Selected Transitional Economies”, Social Responsibility Journal, 5(1):70-82.

OECD (2011), OECD Economic Surveys: Russian Federation, OECD Publishing.

OECD (2012), FDI Restriction Index, OECD Publishing.

OECD (2014), Review of SME and Entrepreneurship Issues and Policies in the Russian Federation, OECD Publishing, forthcoming.

OPORA (2012), The entrepreneurship climate in Russia: Index of OPORA-2012, Moscow.

Public Opinion Foundation (2013), Survey of public opinion.

Pushkarev, O. (2007), "Corruption and Economic Development of Russia: A Regional Aspect", Applied Econometrics, Vol. 6, Issue 2.

Reporters Without Borders (2012), “World Press Freedom Index 2011-2012”.

Reporters Without Borders (2013), "World Press Freedom Index 2013”.

RAC (2013), "Report on Intermediate Results of an Audit of the measures taken by bodies of state power for fulfilment of obligations and realisation of the rights of the Russian Federation, related to joining the WTO, to assess the influence of the WTO regulations and rules on the budget system and sectors of economy", Russian Accounts Chamber, Moscow.

Sobol, E. (2012), "Discaunter ne Letit” (The Discounter Won't Fly), Vedomosti, 30.11.2012, Moscow.

Strategy Partners Group (2013), “CEO Agenda Survey”, Moscow.

Tanzi, V. (1995), “Corruption, Government Activities, and Markets”. 


\section{ECO/WKP(2015)10}

Tarr, D. (2007), "Russian WTO accession: what has been accomplished, what can be expected", Policy Research Working Papers Series 4428, World Bank, Washington, DC.

Transparency International (2013), Corruption Perception Index - 2013.

Transparency International (2013), Global Corruption Barometer.

US Chamber of Commerce (2013), “International Intellectual Property Index”, Global Intellectual Property Center.

Wei, S. (2000), "How Taxing Is Corruption on International Investors", Review of Economics and Statistics 82.

World Bank (2000), Anti-Corruption in Transition: A Contribution to the Policy Debate, WB, Washington, DC.

World Bank (2011), Worldwide Governance Indicators, WB, Washington, DC.

World Bank (2013), Doing Business 2013,WB, Washington, DC.

World Bank (2013), Doing Business 2014, WB, Washington, DC.

World Bank (2013), Policy Note Russian Federation: National and Regional Trends in Regulatory Burden and Corruption, February, WB, Washington, DC.

World Economic Forum (2013), The Global Competitiveness Report 2013-14, WEF, Geneva.

World Economic Forum (2012), The Global Enabling Trade Report 2012, WEF, Geneva. 
ECO/WKP(2015)10

\section{WORKING PAPERS}

The full series of Economics Department Working Papers can be consulted at www.oecd.org/eco/workingpapers

1191. Determinants of female entrepreneurship in India

(March 2015) by Arnaud Daymard

1190. The changing role of the exchange rate for macroeconomic adjustment

(March 2015) by Patrice Ollivaud, Elena Rusticelli and Cyrille Schwellnus

1189. Boosting productivity in Russia: skills, education and innovation

(March 2015) by Lilas Demmou and Andreas Wörgötter

1188. Boosting growth and reducing informality in Mexico

(March 2015) by Sean Dougherty

1187. The conduct of monetary policy in the future: instrument use

(March 2015) by Kei-Ichiro Inaba, Rory O'Farrell, Łukasz Rawdanowicz and Ane Kathrine Christensen

1186. A constant market share analysis of Spanish goods

(February 2015) by Alberto Gonzalez Pandiella

1185. Raising the economic participation of women in India - a new growth engine?

(February 2015) by Piritta Sorsa

1184. Improving health outcomes and health care in India

(January 2015) by Isabelle Joumard and Ankit Kumar

1183. Challenges and opportunities of India's manufacturing sector

(January 2015) by Isabelle Joumard, Urban Sila and Hermes Morgavi

1182. The heterogeneity of product market regulations

(December 2014) by Jean-Marc Fournier

1181. Implicit regulatory barriers in the EU single market: new empirical evidence from gravity models

(December 2014) by Jean-Marc Fournier, Aurore Domps, Yaëlle Gorin, Xavier Guillet and Délia Morchoisne

1180. Can pro-growth policies lift all boats? An analysis based on household disposable income (December 2014) by Orsetta Causa, Alain de Serres and Nicolas Ruiz

1179. Empirical evidence on the effects of environmental policy stringency on productivity growth (December 2014) by Silvia Albrizio, Tomasz Koźluk and Vera Zipperer

1178. The Indicators of the Economic Burdens of Environmental Policy Design - Results from the

OECD Questionnaire

(December 2014) by Tomasz Koźluk

1177. Measuring Environmental Policy Stringency in OECD Countries-A Composite Index Approach (December 2014) by Enrico Botta and Tomasz Koźluk 
1176. Do Environmental Policies Matter for Productivity Growth? Insights from new Cross-Country Measures of Environmental Policies

(December 2014) by Silvia Albrizio, Enrico Botta, Tomasz Koźluk and Vera Zipperer

1175. Making economic growth more socially inclusive

(December 2014) by Andrés Fuentes Hutfilter and Andreas Kappeler

1174. New tax and expenditure elasticity estimates for EU budget surveillance

(December 2014) by Robert W.R. Price, Thai-Thanh Dang and Yvan Guillemette

1173. Moving towards a more dynamic business sector in Spain

(November 2014) by Alberto Gonzalez Pandiella

1172. Better harnessing talent and knowledge to boost sustainable medium-growth in Spain

(November 2014) by David Haugh and Ben Westmore

1171. The internet economy - regulatory challenges and practices

(November 2014) by Isabell Koske, Rosamaria Bitetti, Isabelle Wanner and Ewan Sutherland

1170. A revival of the private rental sector of the housing market? Lessons from Germany, Finland, the Czech Republic and the Netherlands

(October 2014) by Rik de Boer and Rosamaria Bitetti

1169. Secular stagnation: evidence and implications for economic policy

(October 2014) by Lukasz Rawdanowicz, Romain Bouis, Kei-Ichiro Inaba and Ane Kathrine Christensen

1168. Investment gaps after the crisis

(October 2014) by Christine Lewis, Nigel Pain, Jan Strasky and Fusako Menkyna

1167. Factors behind the decline in real long-term government bond yield

(October 2014) by Romain Bouis, Kei-Ichiro Inaba, Łukasz Rawdanowicz and Ane Kathrine Christensen 